\title{
Prediction of face advance rate and determination of the operation efficiency in retreat longwall mining panel using rock engineering system
}

\author{
Sajjad Aghababaei ${ }^{1} \cdot$ Hossein Jalalifar $^{2} \cdot$ Gholamreza Saeedi $^{1}$
}

Received: 16 October 2018/Revised: 3 February 2019/Accepted: 18 March 2019/Published online: 10 April 2019

(C) The Author(s) 2019

\begin{abstract}
A new approach for prediction of face advance rete (FAR) prior to mining operation and determination of the operation efficiency after mining operation in retreat longwall mining panel is presented based upon the concepts of rock engineering system (RES). For this purpose, six longwall panels considered in Parvadeh-I coal mine. Seven major effective parameters on FAR was selected including coal mine roof rating, gas propagation, safety factor of longwall face, ratio of joint spacing to cutting depth at longwall face, longwall face inclination, panel width, floor rock mass rating. To performance evaluation of the presented model, the relationship between the average vulnerability indexes of advance operation with FAR was determined in considered panels with coefficient of determination $\left(R^{2}\right)$ equal to 0.884 that indicate relatively acceptable correlation and compatibility. Investigations of the research indicated that it is possible to determine the actual operation efficiency under fair conditions by a RES-based model. The inevitable reduction of FAR for each longwall panel was determined by presented model that the difference amount between the maximum possible practical face advance rate $\left(\mathrm{FAR}_{\mathrm{mpp}}\right)$ and recorded actual face advance rate $\left(\mathrm{FAR}_{\mathrm{a}}\right)$ indicate the operation efficiency. Applied approach in this paper can be used to prediction of FAR in retreat longwall mining panel for same conditions that can have many benefits, including better and more accurate planning for the sales market and mine operation. Also, presented method in this paper can be applied as a useful tool to determination of actual operation efficiency for other sections and extraction methods in coal mines.
\end{abstract}

Keywords Face advance rate $\cdot$ Rock engineering systems $\cdot$ Operation efficiency $\cdot$ Longwall mining $\cdot$ Parvadeh-I coal mine

Hossein Jalalifar

jalalifar@uk.ac.ir

Sajjad Aghababaei

aghababaies@gmail.com

Gholamreza Saeedi

gsaeedi@uk.ac.ir

1 Mining Engineering Department, Shahid Bahonar University of Kerman, Kerman, Iran

2 Mining and Petroleum Engineering Department, Shahid Bahonar University of Kerman, Kerman, Iran

\section{Introduction}

Prediction of face advance rate (FAR) in longwall panels has many benefits, including better and more accurate planning for the sales market, preparation of next longwall panels, technical-economic analysis for the purchase of new equipment, simultaneous extraction in multiple seams mining and other. The main parameters affecting FAR include gas propagation, roof and floor conditions, panel width and other. Each of these parameters in their bad conditions can reduce the FAR, alone or in interaction with each other. The contribution and magnitude of the effect of each parameter on the reduction of FAR can be determined using the rock engineering system (RES) method.

In this paper, a new RES-based model is presented to prediction of face advance rate (FAR) prior to mining and 
investigation of operation efficiency at retreat longwall face. In this paper, $\mathrm{E}_{0}, \mathrm{E}_{2}, \mathrm{E}_{3}, \mathrm{~W}_{0}, \mathrm{~W}_{1}$ and $\mathrm{W}_{2}$ panels in Parvadeh-I coal mine are taken into account. Extraction time sequence of these panels is equal to $E_{2}, W_{1}, W_{0}, E_{0}$, $\mathrm{W}_{2}, \mathrm{E}_{3}$, respectively. The first extracted panel was $\mathrm{E}_{1}$ that due to the lack of data is not considered in this study. In $\mathrm{E}_{2}$ panel, FAR reduce to $0.1 \mathrm{~m} / \mathrm{d}$ for several times due to roof and floor instability.

Parvadeh-I is one of the underground coal mines located in the south- east of Tabas, Iran. A brief summary of geological and geotechnical information about Parvadeh-I coal mine is presented in Table 1 (Adam Consulting engineers 2005; IRASCO et al. 2005a). Figure 1 shows the layout of the panels in Parvadeh-I coal mine. The information about considered panels for this research is presented in Table 2. The control system of powered supports in Parvadeh-I is manual.

In this paper, based on the concept of RES, the most effective parameters on reduction of FAR have been obtained. By using RES, vulnerability index (VI) of advance operation have been determined. This index determine the vulnerability amount of advance operation or in other word, reduction amount of FAR without considering the operating parameters such as level of personnel skills, level of planning, level of performance of the equipment's and the level of overhaul operation. To validate and determine the performance of the presented model, the results obtained of RES-based model were compared with the FAR in considered panels. Finally, by using presented RES-based model and determination of maximum possible theoretical FAR in each panels, an equation have been developed for determination of operation efficiency.

If the level of planning and operation be good and everything be conducted carefully, maximum possible practical FAR in conditions of considered panel (determination by RES-based model and maximum possible theoretical FAR) should be equal to the achieved FAR in practice. Difference between the predicted FAR and operational FAR indicates bad level of operation include level of personnel skills, level of planning, level of performance of the equipment's and the level of overhaul operation.

\section{Rock engineering systems}

The concept of rock engineering systems (RES), introduced by Hudson (1992), is a powerful tool to solve complex engineering problems. The rock engineering systems methodology was used to address and quantify the interactions between the parameters that affect different degrees of the outcome of a rock engineering systems. The key element in the rock engineering systems is the interaction matrix. The interaction matrix is both a basic analytical and a presentational technique for characterizing the important parameters and the interaction mechanisms in a rock engineering system. The generation of the interaction matrix can help in evaluating the weighting of the parameters within the rock mass system as a whole (Fig. 2) (Faramarzi et al. 2013). In the interaction matrix, all parameters affecting the system are located along the leading diagonal of the matrix, and the off-diagonal positions are assigned with values, which describe the degree of the influence of one parameter on the other parameter. The assigning values to off-diagonal cells $(i-j)$ and $(j-i)$ are called coding the matrix. Three procedures that were proposed for numerically coding the interaction matrix are "binary approach", "expert semi-quantitative" (ESQ) method (Hudson 1992) and "continuous quantitative coding" (CQC) method ( $\mathrm{Lu}$ and Latham 1994). In this study, the ESQ method is considered. In this method, the interaction intensity is detonated on a $0-4$ scale, $0,1,2,3$, and 4 representing "no interaction", "weak", "medium", "strong", and "critical" interaction respectively. In the interaction matrix, the sum of a row is called the "cause", value and the sum of a column is the "effect" value denoted as coordinates $(C, E)$ for a particular parameter. The interactive intensity value of each parameter is denoted as the sum of the $C$ and $E$ values $(C+E)$ and it can be used as an indicator of parameter's significance in the system. The percentage value of $(C+E)$ can be used as

Table 1 Geological and geotechnical information about Parvadeh-I coal mine (IRASCO et al. 2005a, b)

\begin{tabular}{ll}
\hline Type of information & Description \\
\hline Total coal reserve & Approximately 98 million ton \\
Main geological units & $20.8-73.4 \mathrm{MPa} / 8 \%-24 \%$ \\
Range of roof strata strength longwall faces/RQD & $32.3-34.1 \mathrm{MPa} / 1 \%-51 \%$ \\
Range of floor strata strength longwall faces/RQD & $2 \mathrm{~m}, 22^{\circ}$, and $6 \mathrm{MPa}$ \\
Coal seam thickness, dip and compressive strength & North east/south west \\
Orientation of larger horizontal stress (Sh) &
\end{tabular}




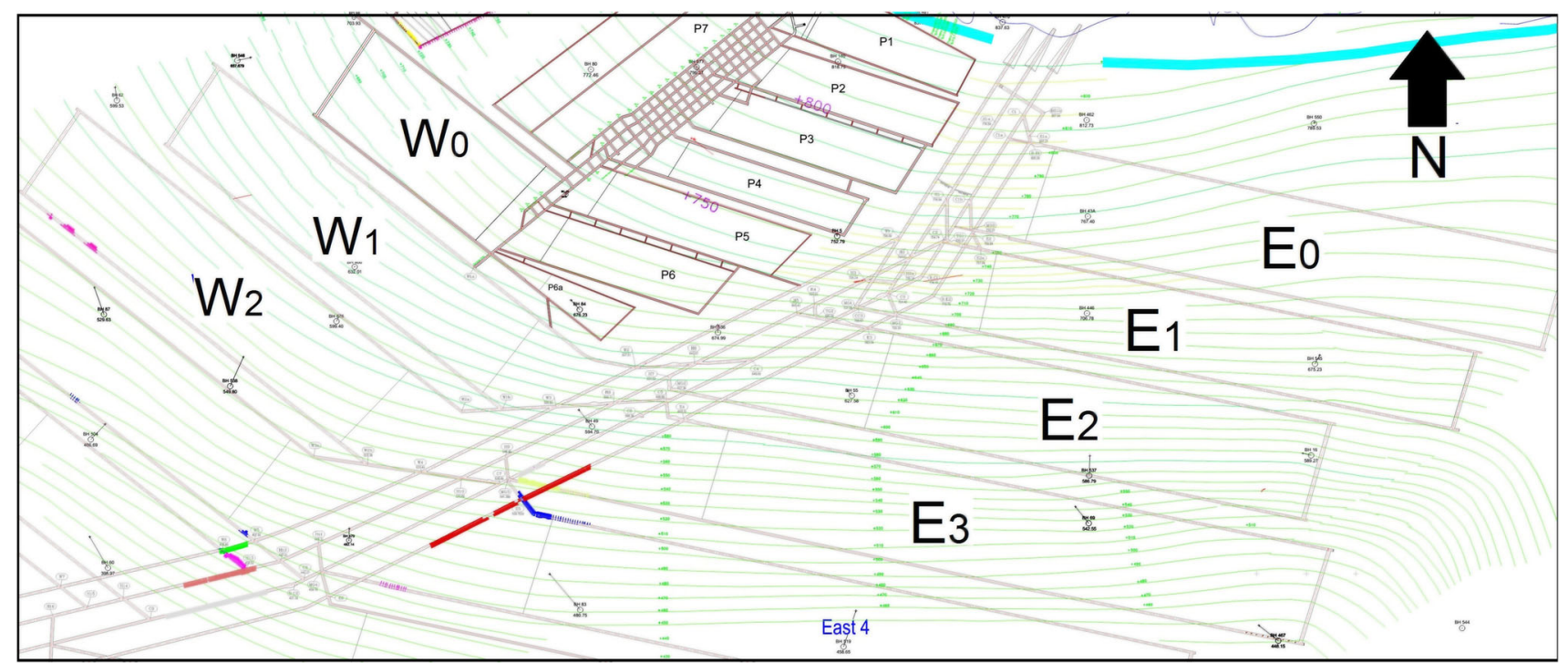

Fig. 1 A plan view of layout of the $E_{0}, E_{2}, E_{3}, W_{0}, W_{1}$ and $W_{2}$ panels in Parvadeh-I coal mine

Table 2 Information about considered panels of Parvadeh-I coal mine

\begin{tabular}{lllllll}
\hline $\begin{array}{l}\text { Panel } \\
\text { code }\end{array}$ & $\begin{array}{l}\text { Depth } \\
(\mathrm{m})\end{array}$ & $\begin{array}{l}\text { Average dip of coal } \\
\text { seam }\left({ }^{\circ}\right)\end{array}$ & $\begin{array}{l}\text { Panel width } \\
(\mathrm{m})\end{array}$ & $\begin{array}{l}\text { Ave. gas propagation }\left(\mathrm{m}^{3} /\right. \\
\text { t.coal })\end{array}$ & $\begin{array}{l}\text { Ave. face advance rate } \\
(\mathrm{m} / \mathrm{d})\end{array}$ & Description \\
\hline $\mathrm{E}_{0}$ & 95 & 12.4 & 198 & 13.15 & 1.41 & Extracted \\
$\mathrm{E}_{2}$ & 250 & 24.9 & 213 & 12.86 & 4.62 & Extracted \\
$\mathrm{E}_{3}$ & 368 & 19 & 207 & 1.6 & 4.87 & $\begin{array}{c}\text { Is extracting (Sep. } \\
2018)\end{array}$ \\
$\mathrm{W}_{0}$ & 180 & $<15$ & 207 & 8.8 & 5.47 & Extracted \\
$\mathrm{W}_{1}$ & 260 & 15.7 & 190.5 & 13.69 & 2.94 & Extracted \\
$\mathrm{W}_{2}$ & 365 & 12.8 & 205.5 & 17.19 & 2.91 & Extracted \\
\hline
\end{tabular}

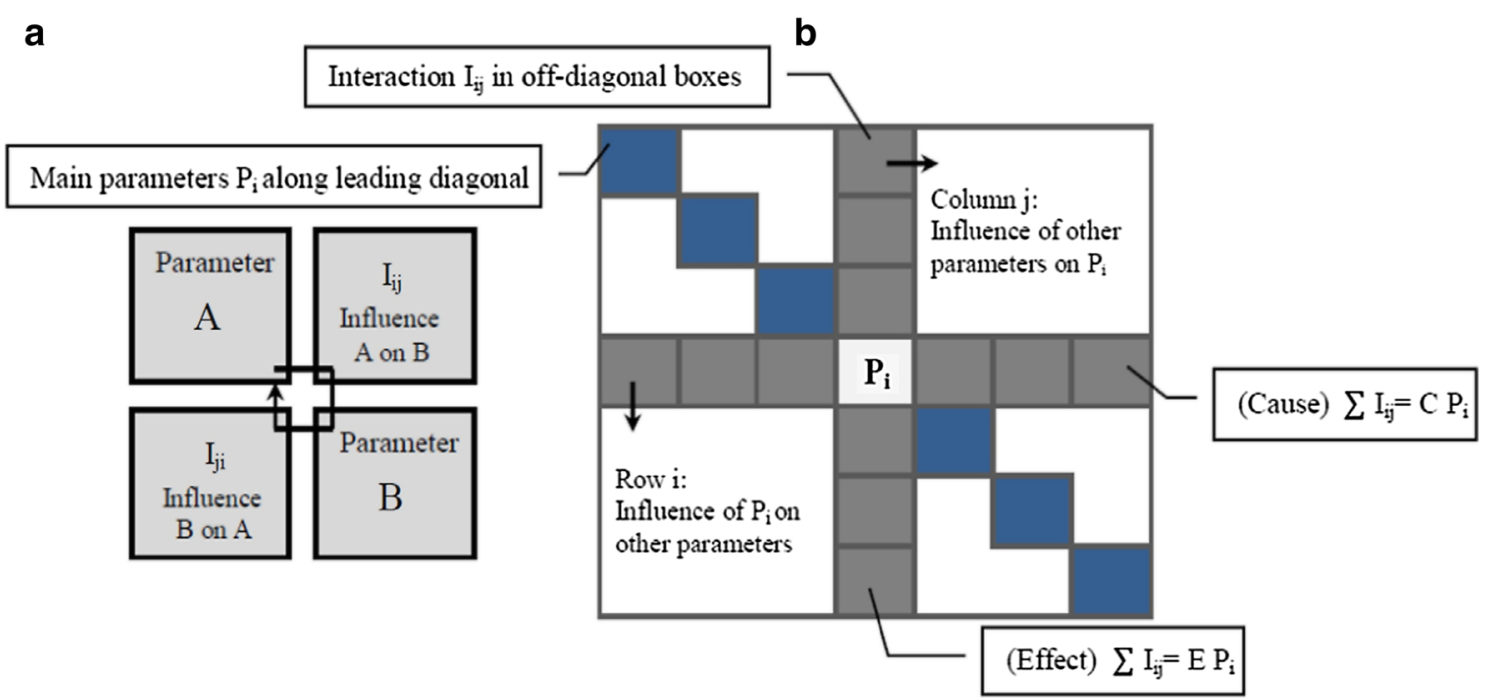

Fig. 2 Interaction matrix in a rock engineering systems, a two parameters interaction matrix; $\mathbf{b}$ a general view of the coding of interaction matrix (Faramarzi et al. 2013) 
the parameter's weighting factor $\left(a_{i}\right)$ as follows (Bahri Najafi et al. 2014):

$a_{i}=\frac{\left(C_{i}+E_{i}\right)}{\left(\sum_{i=1}^{n} C+\sum_{i=1}^{n} E\right)}$

where $C_{i}$ is the cause of the $i$ th parameter, $E_{i}$ is the effect of the ith parameter.

\section{Methodology of research}

In this research, determination of the vulnerability index (VI) of advance operation refers to the rate of reduction of FAR under bad conditions of main effective parameters. Using collection of pre-existing information include geological, geotechnical and operational information and recorded data include geological and geotechnical data that surveyed along the each roadway along the panel roadways, the VI of advance operation was predicted for considered points along the tailgate and main gate of each panel. These points located along the panel gates with equal interval; for example, strap 970-1010 $\mathrm{m}$ in tailgate of $E_{2}$ panel is identified by point 1000 . The amounts of FAR and each parameters were determined for each of points and then, VI of advance operation was determined for them. In the next step, the recorded actual FAR in each panels compared with determined VI's to evaluation of models performance.

In this paper, three main steps considered to identify the new model for determination of the VI of advance operation and its effect on FAR at longwall face are:

Step 1 selecting the effective parameters on FAR and evaluate the $a_{i}$ by RES.

Step 2 determining the VI using Eq. (2) (Benardos and Kaliampakos 2004).

$\mathrm{VI}=100-\sum_{i=1} a_{i} \frac{Q_{i}}{Q_{\max }}$

where $a_{i}$ is the weighting of the $i$ th parameter, $Q_{i}$ is the value (rating) of the $i$ th parameter, and $Q_{\max }$ is the maximum value assigned for ith parameter (normalization factor). When the VI value is approaching 0 the risk level of the hazard is lower, while its value approaching 100 shows that the risk level of the hazard is higher, at the considered site.

Step 3 investigating the relation between VI of advance operation and FAR to evaluation of RES-based model performance.

In step 2, an methodology similar to the work carried out by Benardos and Kaliampakos (2004) is adopted to define a model to determine the VI of advance operation in longwall panels and determination of the performance of presented RES-based model by investigation of the correlation between the estimated VI and face advance rate (FAR) for considered panels.

To investigate of operation efficiency, Eq. (3), (4) and (5) was developed, respectively.

$\mathrm{FAR}_{\text {mpt }}=\left[\frac{\frac{P W}{E S h S}+U S T}{\mathrm{TOC}}\right] W W$

$\mathrm{FAR}_{\mathrm{mpp}}=\left[\frac{(100-\mathrm{VI})}{100}\right] \mathrm{FAR}_{\mathrm{mpt}}$

$E=\left(\frac{\text { FARa }}{\text { FARmpp }_{\text {mp }}}\right) 100$

In Eqs. (3), (4) and (5), FAR $\mathrm{mpt}_{\text {is }}$ ine maximum possible theoretical FAR (m/d), PW is the panel width, EShS is the equivalent shearer machine speed in condition of manual control system for powered supports in Parvadeh-I (considered equal to $16 \mathrm{ft} / \mathrm{min}$ (Oraee 2011), UST is the unavoidable stop times due to work of equipment's at longwall face, TOC is the total useful working time in a day (is equal to $1080 \mathrm{~min}$, in normal conditions), WW is the web width of shearer machine (equal to $0.8 \mathrm{~m}$ for cutter machine in Parvadeh-I), FAR $_{\text {mpp }}$ is the maximum possible practical face advance rate, VI is the vulnerability index of advance operation in considered panel, FAR $_{a}$ is the recorded actual face advance rate in considered panel and $\mathrm{E}$ is the operation efficiency in considered panel $(\%)$.

If the level of planning and operation be good and any things be done carefully, FAR $_{\text {mpp }}$ in conditions of considered panel must be equal to achieved FAR in practice, therefore, $E$ equal to $100 \%$. Difference between the FAR $_{\text {mpp }}$ and FAR $\mathrm{F}_{\mathrm{a}}$ indicates low efficiency and bad level of operation include level of personnel skills, level of planning, level of performance of the equipment's and the level of overhaul operation of the equipment's.

\section{An RES-based model generation}

\subsection{Selection of effective parameters affecting advance operation in longwall face}

Increase of gas propagation more than allowable amount, roof fall and floor failure are main hazards that reduce the FAR in longwall face. Many parameters affect the roof stability, floor stability, and level of gas propagation that simultaneous these parameters affect the advance operation at a longwall face. Based on the investigations in this research, seven major contributing parameters on FAR at a 
longwall mining face are considered to the RES-based model and performing the interaction matrix (Table 3).

$\mathrm{SF}=\frac{\frac{\sigma_{\mathrm{c} w}}{\sigma_{\mathrm{yy}}}}{f}$

where SF is the safety factor of coal face, $\sigma_{\text {c.w }}$ is the wall coal strength of $0.75 \mathrm{~m}$ in width, $\sigma_{\mathrm{yy}}$ is the vertical induced stress at a $0.75 \mathrm{~m}$ distance from the coal face, and $f$ is the correction factor of joint orientation at a coal seam. $F$ is equal to $(1-B)$ that $B$ is orientation factor for critical joint set.

In this research, influence of underground water and depth of panel is considered indirectly by CMRR and safety factor of face, respectively. The effect of transitional geology on FAR investigated by (Jun et al. 2016) but, any reports about this parameters is not recorded in the Parvadeh-I coal mine. The control system of powered supports is the other main parameter that affects the FAR in longwall face. Currently, there is only one longwall system in the Parvadeh-I coal mine and the control system of powered supports is manual.

\subsection{Reaction matrix}

Based on the selected seven parameters, interactive matrix was formed as shown in Table 4 for FAR. $a_{i}$ value for the principal parameters of the FAR are illustrated in Fig. 3. $a_{i}$ values represent the interactive intensity value of each parameter. As it could be seen in the table, panel width $\left(\mathrm{P}_{6}\right)$, safety factor of coal face $\left(\mathrm{P}_{3}\right)$ and the ratio of joint
Table 4 Interaction matrix for the parameters affecting the FAR

\begin{tabular}{lllllll}
\hline $\mathrm{P}_{1}$ & 0 & 1 & 0 & 0 & 3 & 0 \\
\hline 0 & $\mathrm{P}_{2}$ & 0 & 0 & 0 & 1 & 0 \\
0 & 1 & $\mathrm{P}_{3}$ & 0 & 0 & 1 & 0 \\
2 & 1 & 1 & $\mathrm{P}_{4}$ & 0 & 2 & 1 \\
0 & 0 & 1 & 0 & $\mathrm{P}_{5}$ & 1 & 0 \\
0 & 2 & 1 & 0 & 0 & $\mathrm{P}_{6}$ & 0 \\
0 & 0 & 1 & 0 & 1 & 3 & $\mathrm{P}_{7}$ \\
\hline
\end{tabular}

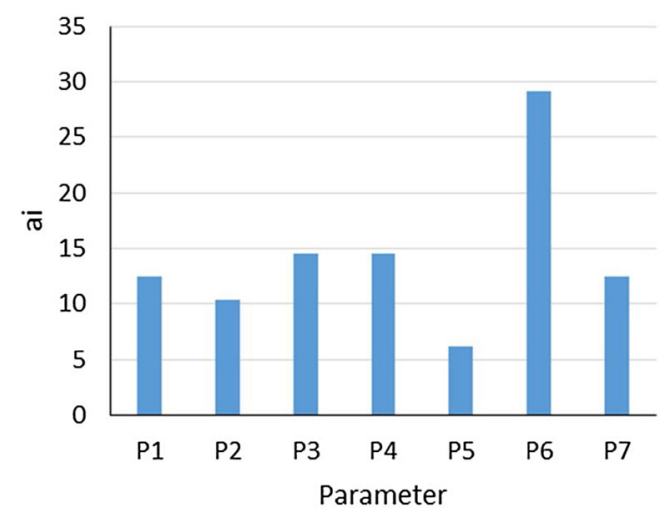

Fig. 3 Weighing of the principal parameters affecting the FAR

spacing to cutting depth at face $\left(\mathrm{P}_{4}\right)$ appeared to have the highest weights in the system and could highly influence the other elements.

Table 3 Selected parameters influencing the FAR at longwall face to RES-based model

\begin{tabular}{|c|c|c|}
\hline Parameter & Code & Description \\
\hline $\begin{array}{l}\text { CMRR (coal mine roof rating) (Mark } \\
\text { and Molinda 1994) }\end{array}$ & $\mathrm{P}_{1}$ & $\begin{array}{l}\text { This parameter is considered by many researches and has a great effect on occurrence of roof } \\
\text { instability in coal mines }\end{array}$ \\
\hline Gas propagation & $\mathrm{P}_{2}$ & $\begin{array}{l}\text { Rising the amount of gas propagation from the permissible limit causes stop the advance } \\
\text { operation. In the mechanized longwall systems, the equipment's is equipped with gas sensors } \\
\text { and the operation be stopped without human intervention by fully mechanized systems }\end{array}$ \\
\hline Safety factor of coal face (SF) & $\mathrm{P}_{3}$ & $\begin{array}{l}\text { Failure and falling the face causes increase of unconfined span and induce the lateral forces on } \\
\text { floor and roof immediate layers that affect the FAR Eq. (4) is considered to determining the } \\
\text { SF (Aghababaei et al. 2015) }\end{array}$ \\
\hline $\begin{array}{l}\text { The ratio of joint spacing to cutting } \\
\text { depth at face }\end{array}$ & $\mathrm{P}_{4}$ & $\begin{array}{l}\text { The ratio of joint spacing to cutting depth at face was considered to express the joints effect. } \\
\text { The number of joints into the unconfined span at face have an important influence on increase } \\
\text { the possibility of sudden roof fall that causes stop the advance operation }\end{array}$ \\
\hline $\begin{array}{l}\text { longitudinal inclination of a longwall } \\
\text { face }\end{array}$ & $\mathrm{P}_{5}$ & $\begin{array}{l}\text { Increase of longitudinal inclination of a longwall face causes reduction of shearer speed, } \\
\text { heterogeneous loading of powered supports and reduction of operation efficiency }\end{array}$ \\
\hline Panel width, face length & $\mathrm{P}_{6}$ & $\begin{array}{l}\text { The wider panels results more convergence, more deflection, more support loads required, more } \\
\text { gas propagation and others problematic factors that all of these reduce the FAR }\end{array}$ \\
\hline Floor RMR & $\mathrm{P}_{7}$ & $\begin{array}{l}\text { Adverse loading conditions of powered supports on the floor will certainly affect the stability of } \\
\text { the roof in a longwall face. For example, references (Bahri Najafi et al. 2014) and (Ghasemi } \\
\text { et al. 2012) had considered this parameter in their models }\end{array}$ \\
\hline
\end{tabular}




\subsection{Rating of parameters}

In order to calculate the $Q_{i} / Q_{\max }$ in Eq. (3), the rating of parameters' value was obtained based on their effect on FAR. Totally, six classes of rating, ranging from 0 to 5 , were taken into account, where 0 denotes the worst case (maximum effect on reduction of FAR) and 5 is the best case (minimum effect on reduction of FAR). For FAR, on the basis of experts' views and also investigation and results of this research, the rating for each parameter is revealed in Tables 5. For example, as it can be seen in Table 5, based on the conducted studies, in a wider to much wider panels, the high volume of roof falls, high roof loading, high roof convergence and high level of gas propagation, result in reduction of FAR at longwall face (high level of VI); therefore, a rating of 0 or 1 was considered. In addition, in narrower panels (less than $100 \mathrm{~m}$ ), since the volume of roof falls is low, the loading and convergence is low to very low, gas propagation level is low, result in high FAR (low level of VI); consequently, a rating of 4 was considered.

\subsection{Determining the VI of FAR and evaluation of model performance}

To determine the VI of FAR at retreat longwall mining face, Eq. (2) was used. For this purpose, $E_{0}, E_{2}, E_{3}, W_{0}, W_{1}$ and $\mathrm{W}_{2}$ panels were taken into account in Parvaadeh-I coal mine. Description of FAR and determined VI's on considered panels are presented in Tables 6 and 7, respectively. Furthermore, performance of the presented RESbased model can be proven by correlation between the estimated VI's and FAR at the considered panels. For this purpose, the correlation and determination coefficient $\left(R^{2}\right)$ between the mean of estimated VI's and FAR ${ }_{a}$ for considered panels is presented in Figs. 4 and 5.

To determine the best and most realistic prediction of FAR in considered condition, the results of several linear and non-linear regression methods were compared to each other and two most appropriate methods were selected (Fig. 6). The maximum available FAR is equal to 9 to $10 \mathrm{~m} / \mathrm{d}$ in the best conditions at Parvadeh-I coal mine. The maximum available FAR was announced equal to 9 meters per day by mining engineers in the best conditions at Parvadeh-I coal mine. Also, the maximum available FAR was estimated equal to $14-16 \mathrm{~m} / \mathrm{d}$ for considered panels based on existence longwall face equipment's, presented equations in this research and panel width. Therefore, at about maximum available FAR, the linear regression appeared to be the best fit. On the other hand, the FAR must be equal to 0 at VI close to or equal to 100 that in this regard, the logarithmic regression shows the best fit. Finally, by combining linear regression with logarithmic regression, an equation was proposed to prediction of FAR in conditions of Parvadeh-I coal mine (Fig. 7).

The relationship between the CMRR, gas propagation, safety factor of longwall face, ratio of joint spacing to cutting depth, longwall face inclination, panel width and floor RMR (quantitative parameters) with FAR was investigated and results are presented in Figs. 8, 9, 10, 11, 1213 and 14, respectively. In this regard, description of average amount of parameters are illustrated in Table 8 . The sensitivity analysis showed that the FAR is most sensitive to variety in of panel width, longwall face inclination and gas propagation, respectively. According to these results, selection of the optimum panel width and

Table 5 Rating of the principal parameters effect in the advance operation or FAR

\begin{tabular}{|c|c|c|c|c|c|c|c|}
\hline \multirow{2}{*}{$\frac{\text { Parameter code }}{\mathrm{P}_{1}}$} & \multicolumn{7}{|c|}{ Value/description and rating } \\
\hline & Value & $<21$ & $21-40$ & $41-60$ & $61-80$ & $81-100$ & \\
\hline & Rating & 0 & 1 & 2 & 3 & 4 & \\
\hline \multirow[t]{2}{*}{$\mathrm{P}_{2}$} & Value & $<5$ & $5-10$ & $10-15$ & $15<$ & Doing gasification & \\
\hline & Rating & 3 & 2 & 1 & 0 & 3 & \\
\hline \multirow[t]{2}{*}{$\mathrm{P}_{3}$} & Value & $<0.75$ & $0.75-1$ & $1-1.25$ & $1.25<$ & & \\
\hline & Rating & 0 & 1 & 2 & 3 & & \\
\hline \multirow[t]{2}{*}{$\mathrm{P}_{4}$} & Value & $<0.25$ & $0.25-0.5$ & $0.5-0.75$ & $0.75-1$ & $1-1.25$ & $1.25<$ \\
\hline & Rating & 0 & 1 & 2 & 3 & 4 & 5 \\
\hline \multirow[t]{2}{*}{$\mathrm{P}_{5}$} & Value & $<15$ & $15-30$ & $30-45$ & $45<$ & & \\
\hline & Rating & 3 & 2 & 1 & 0 & & \\
\hline \multirow[t]{2}{*}{$\mathrm{P}_{6}$} & Value & $<100$ & $100-150$ & $150-200$ & $200-300$ & $300<$ & \\
\hline & Rating & 4 & 3 & 2 & 1 & 0 & \\
\hline \multirow[t]{2}{*}{$\mathrm{P}_{7}$} & Value & $<21$ & $21-40$ & $41-60$ & $61-80$ & $81-100$ & \\
\hline & Rating & 0 & 1 & 2 & 3 & 4 & \\
\hline
\end{tabular}


Table 6 Description of FAR for considered panels in Parvadeh-I coal mine

\begin{tabular}{|c|c|c|c|c|c|}
\hline Panel code & Ave. & Min & Max & SD & Outlier data (based on $\pm 2 \mathrm{SD}$ ) $\%$ \\
\hline $\mathrm{E}_{0}$ & 5.47 & 2.00 & 7.79 & 1.47 & 4.7 \\
\hline $\mathrm{E}_{2}$ & 1.41 & 0.34 & 4.98 & 0.91 & 4.4 \\
\hline $\mathrm{E}_{3}$ & 2.94 & 0.87 & 4.85 & 1.17 & 0 \\
\hline $\mathrm{W}_{0}$ & 4.87 & 2.65 & 6.57 & 1.15 & 0 \\
\hline $\mathrm{W}_{1}$ & 4.62 & 2.06 & 7.11 & 1.50 & 0 \\
\hline $\mathrm{W}_{2}$ & 2.91 & 1.55 & 4.21 & 0.66 & 1.2 \\
\hline
\end{tabular}

Table 7 Description of determined VI's for considered panels in Parvadeh-I coal mine (remove outlier data from $\mathrm{E}_{3}$ )

\begin{tabular}{llllll}
\hline Panel code & Ave. VI & Min VI & Max VI & SD & Outlier data (based on \pm 2 SD) $\%$ \\
\hline $\mathrm{E}_{0}$ & 36.72 & 33.47 & 48.47 & 4.67 & 2.8 \\
$\mathrm{E}_{2}$ & 69.92 & 54.51 & 85.07 & 7.12 & 3.3 \\
$\mathrm{E}_{3}$ & 60.73 & 59.24 & 64.44 & 1.24 & 3.8 \\
$\mathrm{~W}_{0}$ & 47.30 & 42.36 & 60.07 & 6.61 & 0 \\
$\mathrm{~W}_{1}$ & 49.74 & 43.75 & 66.67 & 6.80 & 6.2 \\
$\mathrm{~W}_{2}$ & 54.64 & 54.51 & 56.60 & 0.50 & 6.0 \\
\hline
\end{tabular}

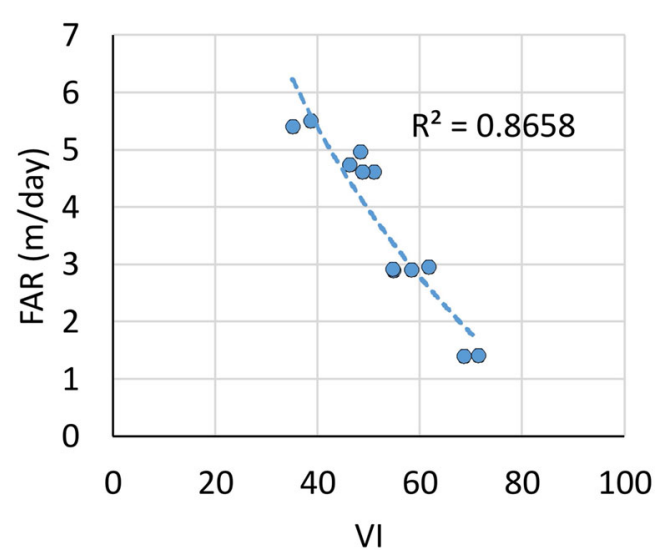

Fig. 4 Relationship between mean of VI's and FAR in each of the gates of panels, a logarithmic regression analysis

gasification operation of deeper panels must be one of the most major concerns in Parvadeh-I mine. Determination of the relation between the selected parameters and $\mathrm{FAR}_{\mathrm{a}}$ can show the success rate in selecting these parameters. Although this may not be a perfect criterion for this purpose, because in the RES the interaction between the parameters is considered, the mean of each parameter was considered in each panel and the conditions of each site may vary from another site, but it can be one of the criteria (Table 9).

However, influence of joint spacing at unconfined span of face is definite on roof fall and FAR but, according to the obtained results from sensitivity analysis, the effect of

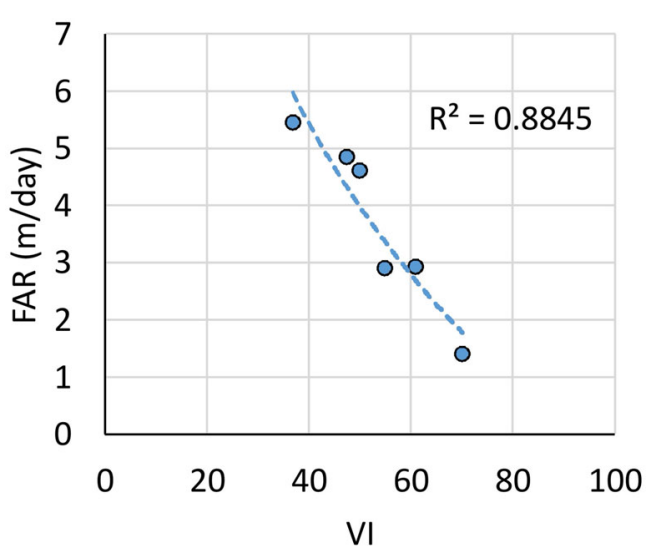

Fig. 5 Relationship between mean of VI's and FAR in each panel, a logarithmic regression analysis

removing $\mathrm{P}_{4}$ was investigated and results are presented in Fig. 15.

\section{Determination of operation efficiency in longwall mining face}

Achieving a way to measure the efficiency of operations and personnel is very important. This may be a bit more complicated in underground coal mines, where there is a lot of hazards and the extraction of operations can be affected by inevitable conditions. Here, using the presented RES-based model, the inevitable reduction of FAR was 


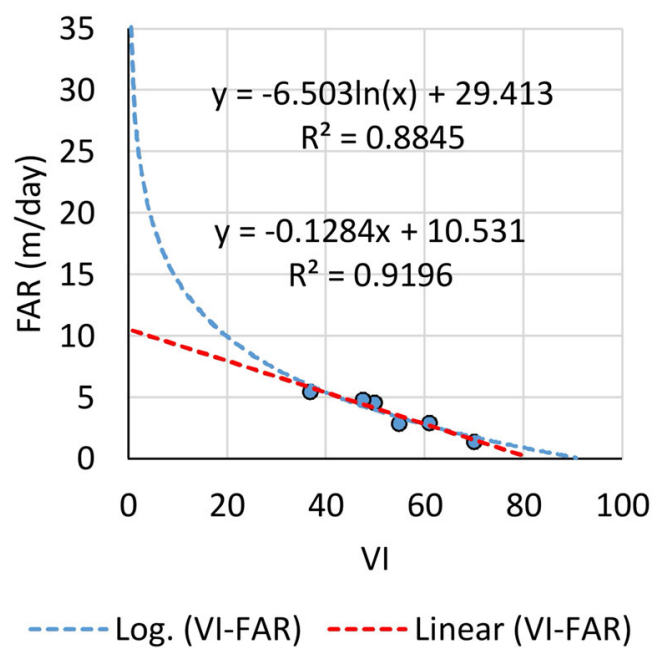

Fig. 6 Comparing the exponential regression with linear regression, from mean of VI's and FAR in each panel

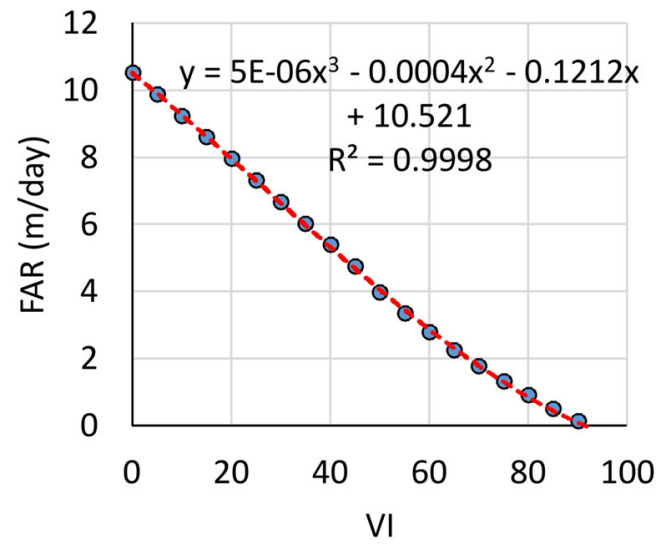

Fig. 7 Calculated final equation to prediction of FAR for Parvadeh-I coal mine

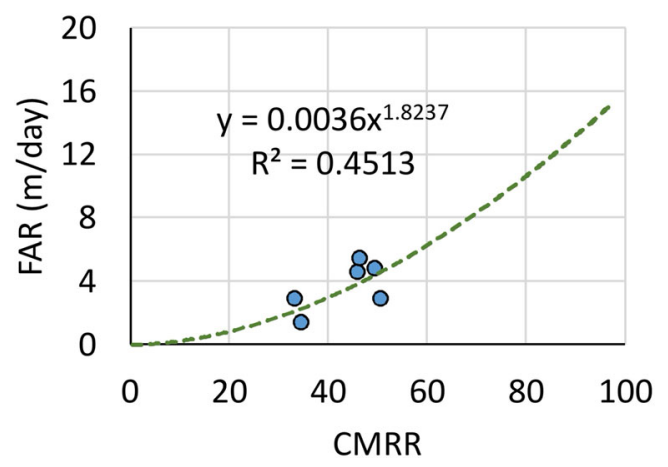

Fig. 8 Relationship between CMRR of panel and FAR, a linear regression analysis

determined for each longwall mining panel. The difference between FAR $_{\text {mpp }}$ and FAR $_{\mathrm{a}}$ shows the operation efficiency (Fig. 16). To determine the operation efficiency in each

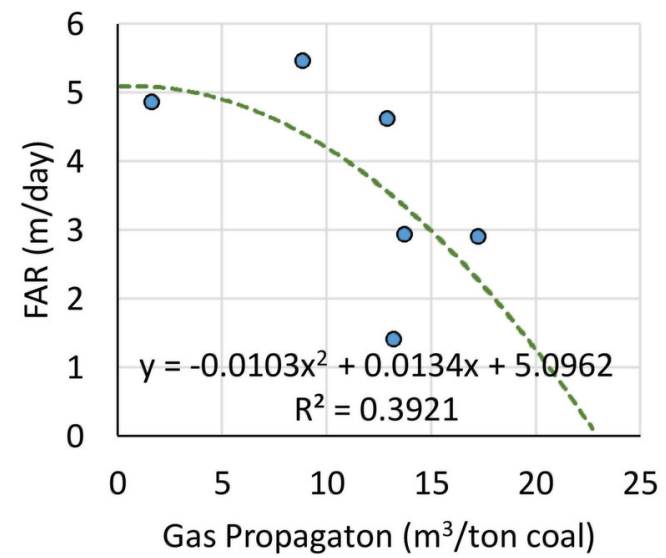

Fig. 9 Relationship between gas propagation and FAR, an exponential regression analysis

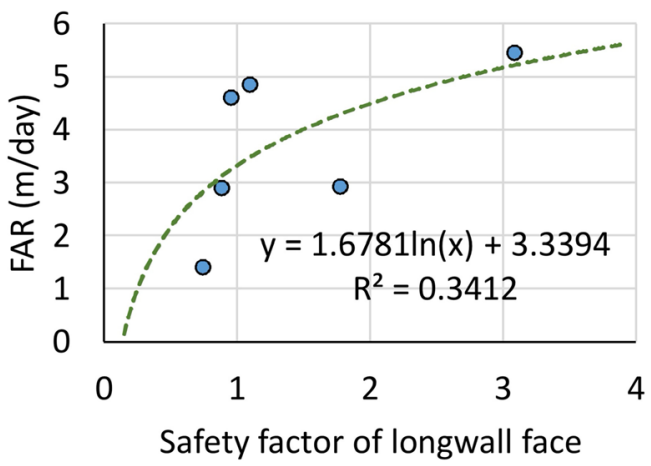

Fig. 10 Relationship between safety factor of longwall face and FAR, a linear regression analysis

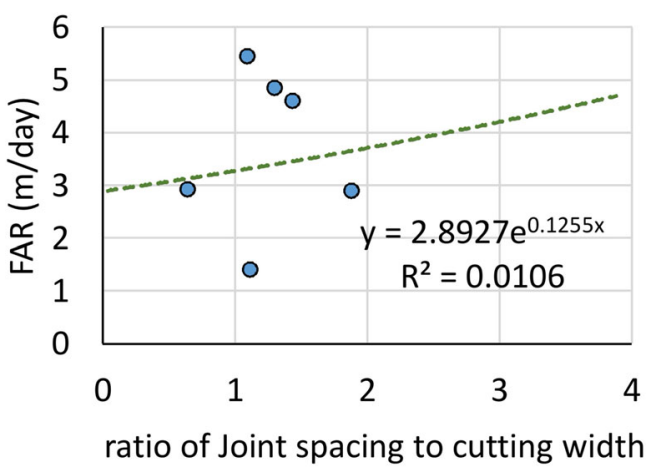

Fig. 11 Relationship between ratio of joint spacing to cutting depth and FAR, an exponential regression analysis

panel, Eqs. (3) to (5) was used and results are presented in Fig. 17.

These results showed that the operation efficiency had been very low in the second extracted panel in Parvadeh-I $\left(\mathrm{E}_{2}\right.$ panel); after an increasing efficiency in next panels, a significant reduction in efficiency in $\mathrm{W}_{2}$ panel was observed. In the $\mathrm{E}_{2}$ panel, there were many problems due to the roof fall and the floor failure, and in the $\mathrm{W}_{2}$ panel, the 


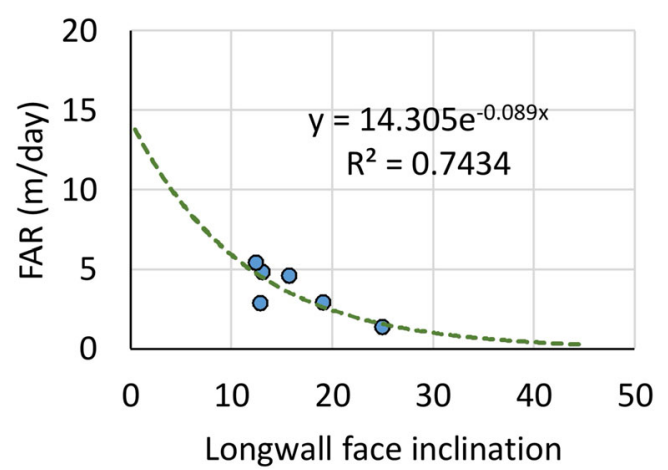

Fig. 12 Relationship between longwall face inclination of face and FAR, a logarithmic regression analysis

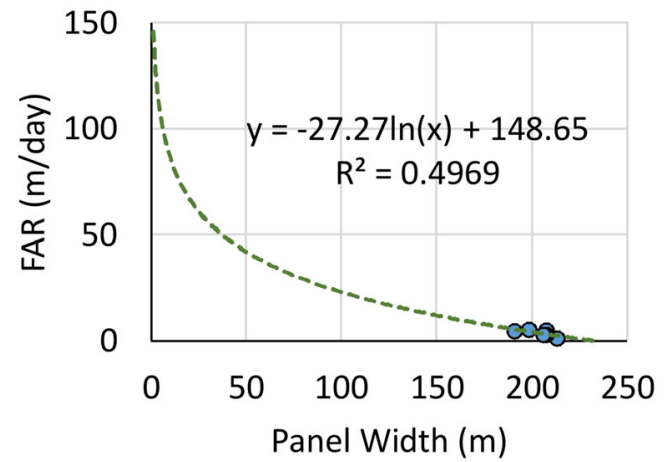

Fig. 13 Relationship between panel width and FAR, a power regression analysis

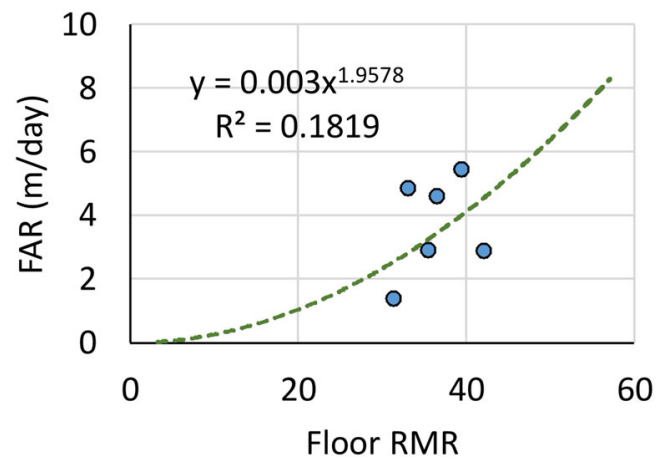

Fig. 14 Relationship between floor RMR and FAR, a linear regression analysis

problems caused by high gas propagation reduced the efficiency. Investigations showed that there had no proper operational reaction in crisis conditions (Fig. 18).

\section{Conclusions}

This research presents a rock engineering system (RES) based model to predict the face advance rate (FAR) and determination of the operation efficiency in retreat
Table 8 Description of average amount of parameters for considered panels in Parvadeh-I coal mine (remove outlier data from basic detail data of $\mathrm{P}_{4}$ )

\begin{tabular}{|c|c|c|c|c|c|}
\hline Parameter & Ave. & Min & Max & SD & $\begin{array}{l}\text { Outlier data } \\
\text { (based } \\
\text { on } \pm 2 \mathrm{SD}) \%\end{array}$ \\
\hline Panel width (m) & 203.5 & 190.5 & 213 & 7.97 & 0 \\
\hline CMRR & 43.16 & 33.07 & 50.38 & 7.55 & 0 \\
\hline $\begin{array}{l}\text { Ratio of joint } \\
\text { spacing to } \\
\text { cutting depth }\end{array}$ & 1.22 & 0.38 & 1.88 & 0.49 & 0 \\
\hline $\begin{array}{l}\text { Safety factor of } \\
\text { longwall face }\end{array}$ & 1.42 & 0.74 & 3.08 & 0.89 & 0 \\
\hline $\begin{array}{l}\text { Longwall face } \\
\text { inclination }\left({ }^{\circ}\right)\end{array}$ & 16.3 & 12.4 & 24.9 & 4.89 & 0 \\
\hline Floor RMR & 36.21 & 31.22 & 42 & 3.98 & 0 \\
\hline $\begin{array}{l}\text { Gas Propagation } \\
\left(\mathrm{m}^{3} / \mathrm{t}\right)\end{array}$ & 11.21 & 1.6 & 17.19 & 5.51 & 0 \\
\hline
\end{tabular}

longwall mining face. For this purpose, six longwall panel considered in Parvadeh-I coal mine. Performance evolution of presented model showed that there is an acceptable correlation and compatibility between the level of determined vulnerability indexes of advance operation and FAR with $R^{2}$ of 0.884 for all estimated VIs in considered panels. RES outputs identified the most effective parameters on FAR in longwall face include panel width, safety factor of longwall face and ratio of joint spacing to cutting depth, respectively.

Sensitivity analysis showed that there is a relationship between the all selected parameters with FAR in ParvadehI coal mine and the FAR is most sensitive to varieties in panel width, longwall face inclination and gas propagation, respectively; According to this results, selection of optimum panel width must be the one of the important concerns in this mine. Upgrading the control system of powered supports can reduce the constraints in increase of panel width.

Investigations of this research indicated that it is possible to determine the actual operation efficiency under fair conditions by a RES-based model. Presented model determined the inevitable reduction of FAR for each longwall panel that the difference amount between the maximum possible practical face advance rate $\left(\mathrm{FAR}_{\mathrm{mpp}}\right)$ and recorded actual face advance rate $\left(\mathrm{FAR}_{\mathrm{a}}\right)$ indicate the operation efficiency.

Applied approach in this paper can be used to prediction of FAR in retreat longwall mining panel for same conditions that has many benefits, including better and more accurate planning for the sales market, preparation of next longwall panels, technical-economic analysis for the purchase of new equipment, simultaneous extraction in 
Table 9 FAR change percentage with increase change percentage of each parameter, change percentage investigated in the direction of increase the FAR

\begin{tabular}{|c|c|c|c|c|c|c|}
\hline Parameter & $\begin{array}{l}\text { SRF change } \\
\text { percentage with } \\
10 \% \text { change }\end{array}$ & $\begin{array}{l}\text { SRF change } \\
\text { percentage with } \\
20 \% \text { change }\end{array}$ & $\begin{array}{l}\text { SRF change } \\
\text { percentage with } \\
30 \% \text { change }\end{array}$ & $\begin{array}{l}\text { SRF change } \\
\text { percentage with } \\
50 \% \text { change }\end{array}$ & $\begin{array}{l}\text { SRF change } \\
\text { percentage with } \\
70 \% \text { change }\end{array}$ & $\begin{array}{l}\text { SRF change } \\
\text { percentage with } \\
90 \% \text { change }\end{array}$ \\
\hline Panel Width & 2446 & 5180 & 8280 & 16,091 & 27,949 & 53,452 \\
\hline $\begin{array}{l}\text { Longwall face } \\
\text { inclination }\end{array}$ & 43 & 104 & 191 & 493 & 1109 & 2363 \\
\hline Gas propagation & 61 & 115 & 162 & 238 & 286 & 308 \\
\hline Floor RMR & 21 & 43 & 67 & 121 & 183 & 251 \\
\hline CMRR & 19 & 39 & 61 & 109 & 163 & 222 \\
\hline $\begin{array}{r}\text { Safety factor of } \\
\text { longwall face }\end{array}$ & 12 & 23 & 33 & 52 & 67 & 82 \\
\hline $\begin{array}{l}\text { Ratio of joint } \\
\text { spacing to } \\
\text { cutting depth }\end{array}$ & 1 & 3 & 4 & 6 & 9 & 12 \\
\hline
\end{tabular}

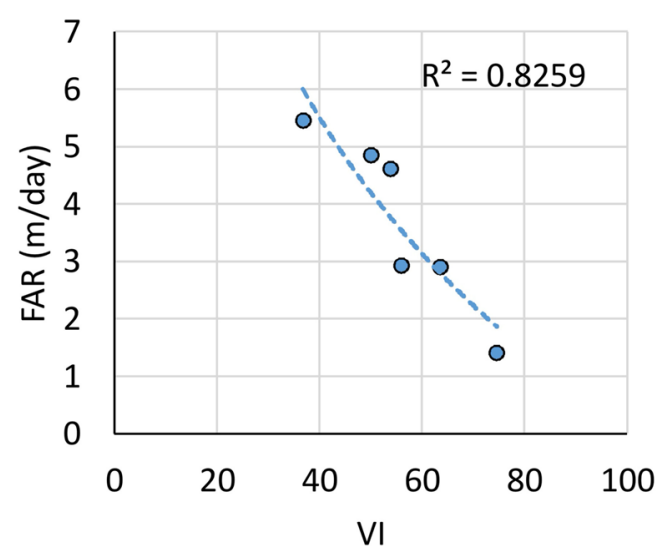

Fig. 15 Relationship between mean of VI's and FAR in each panel, remove $\mathrm{P}_{4}$, a logarithmic analysis

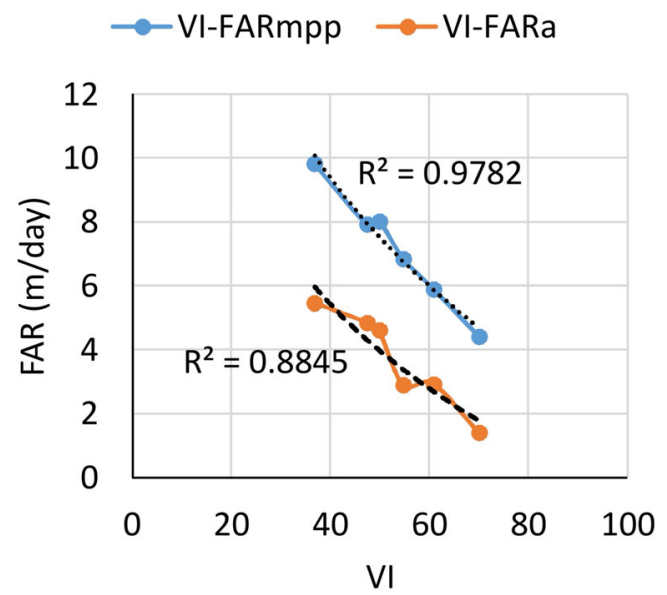

Fig. 16 comparison between the $\mathrm{FAR}_{\text {mpp }}$ and $\mathrm{FAR}_{\mathrm{a}}$ in parvadeh-I coal mine

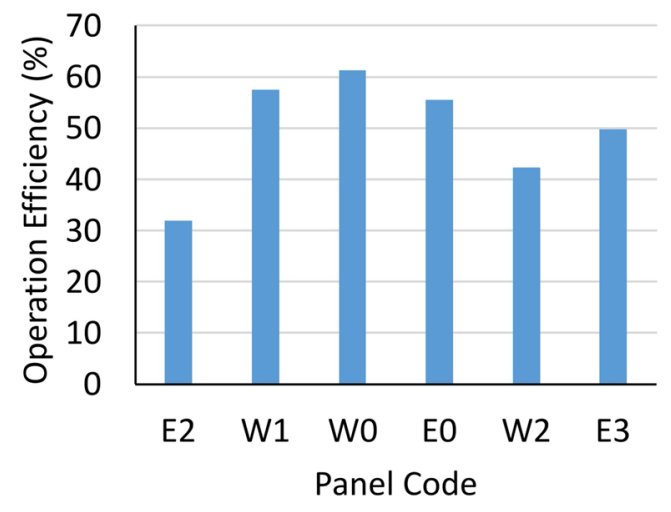

Fig. 17 Determination of operation efficiency in considered panels

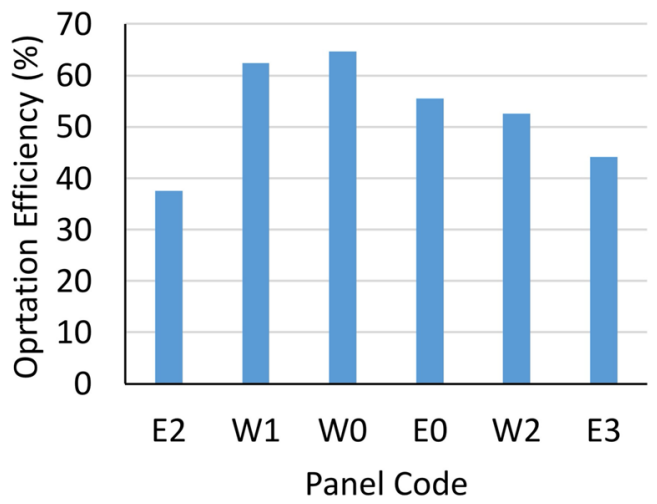

Fig. 18 Determination of operation efficiency in considered panels, in condition of removing $\mathrm{P}_{4}$

multiple seams mining and other. Also, presented method in this paper can be applied as a useful tool to determination of actual operation efficiency for other sections and extraction methods in coal mines. 
Acknowledgements The authors gratefully acknowledge the engineering team in Parvadeh-I Coal Mine (Tabas Parvadeh Coal Company, Tabas, Iran) in particular Ali Keshvari, mine manager, and Ali Hosseini, head of education, for providing access to all required information and all mine sections for this research.

Open Access This article is distributed under the terms of the Creative Commons Attribution 4.0 International License (http://crea tivecommons.org/licenses/by/4.0/), which permits unrestricted use, distribution, and reproduction in any medium, provided you give appropriate credit to the original author(s) and the source, provide a link to the Creative Commons license, and indicate if changes were made.

\section{References}

Adam Consulting engineers (2005) Central mine design. Tabas Coal Mine, Iran

Aghababaei S, Saeedi G, Jalalifar H (2015) Risk analysis and prediction of floor failure mechanisms at longwall face in parvadeh-I coal mine using rock engineering system (RES). Int J Rock Mech Rock Eng. https://doi.org/10.1007/s00603-0150884-x

Bahri Najafi A, Saeedi G, Ebrahimi Farsangi MA (2014) Risk analysis and prediction of out-of-seam dilution in longwall mining. Int J Rock MechSci 70:115-122

Benardos AG, Kaliampakos DC (2004) A methodology for assessing geotechnical hazards for TBM tunneling-illustrated by the Athens Metro, Greece. Int J Rock Mech Min Sci 41:987-999
IRASCO, IRITEC, Cementation SKANSKA (2005a) Basic design report. Appendix A, rating of rock exposures \& Appendix G, geotechnical data. Parvadeh, Tabas Coal Mine Project, Iran

IRASCO, IRITEC, Cementation SKANSKA (2005b) Basic design report. Vol. 2 to 5. Parvadeh, Tabas Coal Mine Project, Iran

Faramarzi F, Mansouri H, Ebrahimi Farsangi MA (2013) A rock engineering systems based model to predict rock fragmentation by blasting. Int J Rock Mech Min Sci 60:82-94

Ghasemi E, Ataei M, Shahriar K, Sereshki F, Jalali SE, Ramenzanzadeh A (2012) Assessment of roof fall risk during retreat mining in room and pillar coal mines. Int J Rock Mech Min Sci 54:80-89

Hudson JA (1992) Rock engineering systems: theory and practice. Ellis Harwood, Chichester

Jun L, Van Dyke M, Daniel WHS, Greg H (2016) Transitional geology and its effects on development and longwall mining in Pittsburgh Seam. Int J Rock Mech Min Sci 26:31-37

Oraee K (2011) Advanced and economical issues in underground mining support. Publication Jihad Amirkabir University, Tehran

Lu P, Latham JP (1994) A continuous quantitative coding approach to the interaction matrix in rock engineering systems based on grey systems approaches. In: Proceedings of the 7th international congress of the international association of engineering geology (IAEG). Balkema pp 4761-70

Mark C, Molinda G (1994) The coal mine roof rating (CMRR)- a practical rock mass classification for coal mines, USBM IC' 9387, p 83 